\title{
Management of Oil Palm's Residues for Utilization: Reduced Amount of Greenhouse Gas
}

\author{
Wisakha Phoochinda ${ }^{1}$ \\ ${ }^{1}$ Graduate School of Environmental Development Administration, National Institute of Development \\ Administration (NIDA), Thailand \\ Correspondence: Wisakha Phoochinda, Graduate School of Environmental Development Administration, \\ National Institute of Development Administration (NIDA), Thailand. E-mail: wisakha.p@nida.ac.th
}

$\begin{array}{ll}\text { Received: May 15, 2018 } & \text { Accepted: August 2, } 2018 \quad \text { Online Published: September 28, } 2018 \\ \text { doi:10.5539/jsd.v11n5p96 } & \text { URL: https://doi.org/10.5539/jsd.v11n5p96 }\end{array}$

\begin{abstract}
As the demand of oil palm outputs in the world market and Thailand has increased, it results in the oil palm's residues which need to be utilized. The study aimed to investigate the utilization of oil palm's residues and analyze the greenhouse gas emission from the utilization of oil palm's residues. The study reviewed related literature to obtain concepts, theories, research works, policies, and measures related to the utilization of oil palm's residues and interviewed to relevant scholars and agencies. The greenhouse gas emission on the utilization of oil palm's residues were calculated and then compared.

The study findings revealed the utilization of the residues and the emission of greenhouse gas as follows: cultivation of straw mushroom from empty palm bunch emitted greenhouse gas $323.1264 \mathrm{KgCO}_{2}$ eq /year; use of oil palm fronds as animal feed emitted greenhouse gas $109.674 \mathrm{KgCO}_{2}$ eq /year; use of empty palm bunch to cover soil emitted greenhouse gas in total $109.674 \mathrm{KgCO}_{2} \mathrm{eq}$ /year; composting from residues from palm oil extracting plants emitted greenhouse gas $210.346 \mathrm{KgCO}_{2} \mathrm{eq} /$ year, compilation of oil palm fronds in heaps revealed no greenhouse gas emission, and composting from palm bunch emitted greenhouse gas 210.346 $\mathrm{KgCO}_{2}$ eq /year.
\end{abstract}

Keywords: oil's palm residues, utilization, greenhouse gases

\section{Introduction}

Oil palm is an important crop and can be processed into various products such as cooking vegetable oil, soap, detergents, cosmetics, and chemicals, as raw materials in the food industry such as cream, margarine, sweetened condensed milk, and other products, as well as use for biodiesel production. The demand of oil palm outputs in the world market and the promotion of the Thai government under the strategies to increase areas for oil palm cultivation have stimulated the increase in cultivation land of 7.24 million rai by 2026 and triggered the farmers to increasingly turn to oil palm cultivation. In 2017, in Thailand, the land for oil palm cultivation accounted for approximately 4.92 million rai, or increase of 360,000 rai from 2016 (Policy and Planning Bureau, Office of the Permanent Secretary for Interior, 2017). As a result, oil palm has become an important economic crop to the national development, with increased yields of oil palm in line with the needs of the global market and the country. The residues from oil palm plantations and palm oil industry each year have increased accordingly such as old palm trees, oil palm fronds, empty palm bunch, palm fruit fiber, palm kernel meal, palm kernel shell, and wastewater from production process. If they were compiled in heaps, the residues will affect the environment, especially the emission of greenhouse gas. Moreover, the old palm trees and discarded empty palm bunch will be the ground for the laying of Asiatic rhinoceros beetles' eggs, which are young palm and coconut eating insects, causing damage to growers (Teerapong Jungniyom, 2008). Therefore, to reduce the impact on the environment, reduce waste into the environment, and reduce the amount of emitted greenhouse gas, and increase value added to oil palm's residues, the researcher conducted the study of the utilization of oil palm's residues and the analysis of the greenhouse gas emission from the utilization of oil palm's residues, as well as provide knowledge on the utilization of oil palm's residues, leading to increased income and reduced costs in oil palm cultivation.

\section{Objectives}

1) To study on the utilization of oil palm's residues 
2) To analyze of the emission of greenhouse gas from the utilization of oil palm' residues

\section{Literature Review}

The utilization of oil palm's residues included the followings : trunks were used as wood planks for walls, ceilings, tables, and other furnitures; oil palm fronds were used to cover soil or materials those between rows of palm trees to preserve moisture in the soil, reduce erosion of soil surface, increase ingredients in the soil and as animal feed; empty fruit bunch (EFB) was used to cover the foot of the palm trees, for fuel, and for straw mushroom cultivation; the tough fiber in the core of empty fruit bunch could replace fiber from coconut shell, with high nutrients (nitrogen $\% 1$, phosphorous $\% 0.7$, and potassium $(\% 3$ and could be used as material in composting; palm kernel meal was mostly used as animal feed due to high nutrients; fiber and shell were used as fuel for boiler; palm kernel shell could be processed into activated carbon to be used to fill the road surface in palm plantations; fiber and shell were used as ingredient for palm seedling or for mulching in palm seedling bag; sludge from palm oil extracting plants (Decanter Cake), pieces of palm fruit shell or other contaminants in palm oil with relatively high protein and calcium, was used as supplement food for milk cows, mixed with empty fruit bunch and palm fruit shell to produce compost; condensate, which was water from boiler would be condensed to yield molasses; wastewater from palm oil extraction, composted in a close system, would yield methane gas, and could be used in various applications such as replacement of LPG, fuel, or power generation (Seksan Papong et al, 2014).

The amount of emitted greenhouse gas from palm plantations with over 50 rai of land revealed that the overall emitted greenhouse gas from land preparation, care, and harvest equaled $2.16 \mathrm{~kg}$. $\mathrm{CO}_{2}$ equivalent per ton of oil palm bunch. The palm plantations with less than50 rai of land revealed that the overall emitted greenhouse gas equaled $1.44 \mathrm{~kg} . \mathrm{CO}_{2}$ equivalent per ton of oil palm bunch (Wisakha Phoochinda, 2015).

\section{Methodology}

Literature review on concepts, theories, research works, and policies and measures of the utilization of oil palm's residues or in relation to oil palm industry; information of the utilization of oil palm's residues from various agencies was carried out and; in-depth study from scholars and agencies related to oil palm production at communal and national levels such as the Oil Palm Grower Cooperatives, Oil Palm Research and Development Center, Department of Agriculture, Ministry of Agriculture and Cooperatives, Federation of Thai Industries (Oil Palm Industry Club), Agricultural Research Development Agency (Public Organization), and other agencies as appropriate were conducted. Interviews were taken into account to acquire policies, measures, and guideline to utilize oil palm's residues; interviews with executives of palm oil extracting plants to study the linkage of the utilization of oil palm's residues between growers, transaction points, and palm oil extracting plants; and field survey in palm plantations and interviews with oil palm growers. 


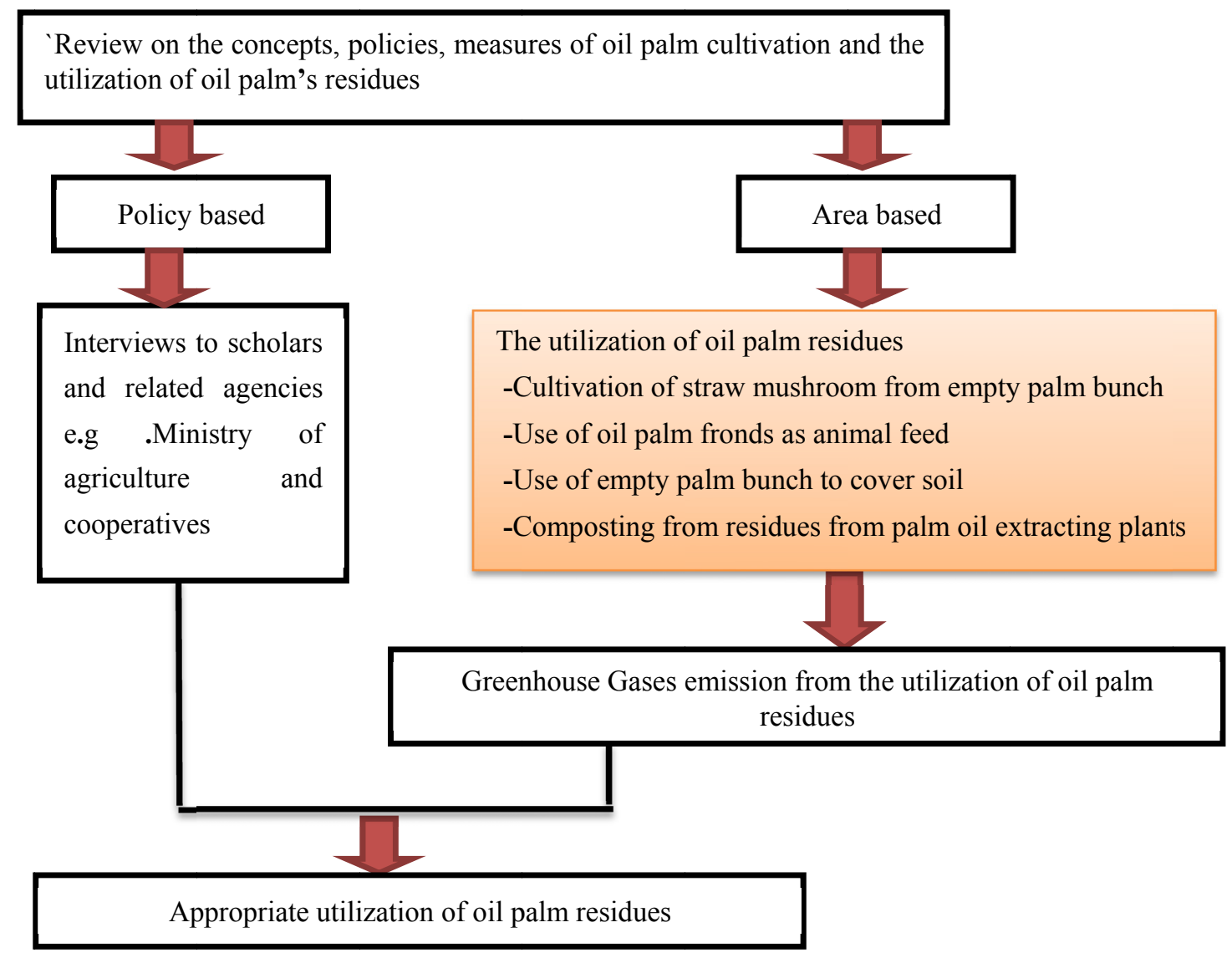

Figure 1. Conceptual framework

The information gathered from the utilization of oil palm's residues would be calculated for the amount of the greenhouse gas emission of each process by using the formula.

\section{GHG $\left(\mathrm{CO}_{2} \mathrm{e}\right)=\mathrm{A} \times \mathrm{EF}$}

$\mathrm{GHG}=$ Amount of greenhouse gas $\left(\mathrm{CO}_{2} \mathrm{e}\right)$

$\mathrm{A}=$ Activity derived from greenhouse gas

$\mathrm{EF}=$ Coefficient of greenhouse gas emission

(Emission Factor) (Unit of $\mathrm{kg} \mathrm{CO}_{2} \mathrm{e} / \mathrm{unit}$ )

\section{Study Findings}

\subsection{Utilization of Oil Palm's Residues}

The study of the information to utilize oil palm's residues, from literature review, interviews with scholars and agencies related to oil palm production and palm oil extracting plants, field survey of oil palm plantations and interviews with oil palm growers revealed that oil palm's residues were diverse such as old palm trees, palm fronds, empty palm bunch, palm kernel meal, waste palm fiber, palm kernel shell, sludge from palm oil extracting plants, wastewater from wastewater treatment pond of palm oil extracting plants. The utilization of the residues was multiple such as cultivation of straw mushrooms from empty palm bunch, use of oil palm fronds as animal feed, use of empty palm bunch to cover soil, composting of residues from palm oil extracting plants, compilation of oil palm fronds in heaps to make compost and preserve moisture in the soil, composting from oil palm bunch, and production of hard fiberboard from oil palm's residues, biomass fuel from palm kernel shell, and biomass energy from wastewater from wastewater treatment pond. By compiling them in heaps, there would be no utilization of oil palm residues and it would affect the emission of greenhouse gas of $518 \mathrm{~kg} . \mathrm{CO}_{2} \mathrm{eq} / 1$ ton (Seksan Papong et al 2014).

\subsection{Reduced Amount of Greenhouse Gas Emission from the Utilization of Oil Palm's Residues}

The management of oil palm's residues in each process impacted the environment by the emission of greenhouse 
gas. The principle of the assessment of the greenhouse gas emission of products of Technical Committee on Carbon Footprint of Products in 2009 was applied to assess the amount of greenhouse gas in each process as illustrated in Table 1.

Table 1. Assessment of the amount of greenhouse gas

\begin{tabular}{|c|c|c|c|}
\hline \multirow[b]{2}{*}{ Utilization of Oil Palm's Residues } & \multicolumn{3}{|c|}{ Amount of Greenhouse Gas (kg.CO ${ }_{2} \mathrm{eq} / \mathrm{year}$ ) } \\
\hline & $\begin{array}{l}\text { Used } \\
\text { amount }\end{array}$ & $\begin{array}{l}\text { Coefficient of } \\
\text { greenhouse gas } \\
\text { emission }\end{array}$ & $\begin{array}{l}\text { kg.CO} \\
\text { unit/year }\end{array}$ \\
\hline \multicolumn{4}{|l|}{ Straw mushroom cultivation from empty palm } \\
\hline $\begin{array}{l}\text { Electricity for blender of straw mushroom media } \\
\text { with food for mushrooms }\end{array}$ & $8 \mathrm{kWh}$ & 0.6093 & 4.8744 \\
\hline Benzene fuel for pump to water palm bunch & 20 liters & 2.1896 & 43.792 \\
\hline $\begin{array}{l}\text { Diesel fuel for tractor to level area, arrange heaps } \\
\text { of palm bunch, and transport palm bunch }\end{array}$ & 100 liters & 2.7446 & 274.46 \\
\hline Total & - & - & 323.1264 \\
\hline \multicolumn{4}{|l|}{$\begin{array}{l}\text { Utilization of oil palm fronds as animal feed } \\
\text { (18 times/year) }\end{array}$} \\
\hline $\begin{array}{l}\text { Electricity for wood shredder } \\
\text { Total }\end{array}$ & $180 \mathrm{kWh}$ & $\begin{array}{l}0.6093 \\
-\end{array}$ & $\begin{array}{l}109.674 \\
\mathbf{1 0 9 . 6 7 4}\end{array}$ \\
\hline \multicolumn{4}{|l|}{100 tons/year } \\
\hline $\begin{array}{l}\text { Diesel fuel for trucks to transport oil palm bunch } \\
\text { Total }\end{array}$ & 70 liters & 2.7446 & $\begin{array}{l}192.122 \\
\mathbf{1 9 2 . 1 2 2}\end{array}$ \\
\hline \multicolumn{4}{|l|}{ Composting from residues from palm oil } \\
\hline $\begin{array}{l}\text { Electricity for grinding palm bunch and for pump } \\
\text { Diesel fuel for trucks to transport residues and for } \\
\text { tractors to turn fertilizer heaps }\end{array}$ & $120 \mathrm{kWh}$ & $\begin{array}{l}0.6093 \\
2.7446\end{array}$ & 137.23 \\
\hline Total & & & 210.346 \\
\hline \multicolumn{4}{|l|}{ Compilation of oil palm fronds in heaps } \\
\hline No utilization of resources & - & - & 0 \\
\hline Total & - & - & $\mathbf{0}$ \\
\hline \multicolumn{4}{|l|}{$\begin{array}{lllll}\text { Composting from empty palm bunch } & 20 \\
\text { tons/year } & & & & \end{array}$} \\
\hline Electricity for grinding palm bunch and for pump & $120 \mathrm{kWh}$ & 0.6093 & 73.116 \\
\hline Diesel fuel for trucks to transport palm bunch & 50 liters & 2.7446 & 137.23 \\
\hline Total & & & 210.346 \\
\hline
\end{tabular}

\section{Conclusions}

The utilization of oil palm's residues can be summarized as in Table 2 . 
Table 2. Utilization of oil palm's residues

\begin{tabular}{ll}
\hline \multicolumn{1}{c}{ Residues } & \multicolumn{1}{c}{ Utilization } \\
\hline Old palm trees & Hard fiberboard \\
Palm fronds & $\begin{array}{l}\text { Animal feed, accumulation on the ground to add } \\
\text { nutrients and preserve moisture to the soil }\end{array}$ \\
Empty palm bunch & $\begin{array}{l}\text { Cultivation of straw mushrooms, compost, } \\
\text { coverage at the foot of the oil palm trees }\end{array}$ \\
Palm kernel meal & Animal feed, compost \\
Waste palm fiber & Hard fiberboard \\
Palm kernel shell & Biomass fuel \\
Sludge from palm oil extracting plants & Compost \\
Wastewater from wastewater treatment pond & Biomass energy \\
\hline
\end{tabular}

The results of the greenhouse gas emission could be summarized as follows. The straw mushroom cultivation of empty palm bunch for 4 times/year would emit in total greenhouse gas $323.1264 \mathrm{KgCO}_{2}$ eq /year; the use of oil palm fronds as animal feed for 18 times/year would emit in total greenhouse gas $109.674 \mathrm{KgCO}_{2}$ eq /year; the use of empty palm bunch to cover soil for 100 tons/year would emit in total greenhouse gas $109.674 \mathrm{KgCO}_{2}$ eq /year; composting from residues of palm oil extracting plants for 20 tons/year would emit in total greenhouse gas $210.346 \mathrm{KgCO}_{2} \mathrm{eq} /$ year; the compilation of oil palm fronds emitted no greenhouse gas, and composting from oil palm bunch for 20 tons/year would emit in total greenhouse gas $210.346 \mathrm{KgCO}_{2}$ eq /year.

\section{Discussions}

The utilization of oil palm's residues can be summarized as follows:

1) Old palm trees with over 25 years old will give lower yield. Growers will cut them down and replant new trees. The palm trunks can be utilized by chopping them into small pieces and compiling them for degradation, or tillage into the soil to add nutrients in the soil. It can be used to produce hard fiberboard and wood-replacing material. The activities are in line with Woratham Oonjittichai (1998) who wrote that agricultural and industrial residues such as trees, branches, leaves, and empty palm bunch could be produced as natural wood replacing products.

2) Empty palm bunch can be used for the cultivation of straw mushrooms, composting, and biomass energy, the use of palm fronds to cover the foot of palm trees, or between rows of palm trees will preserve moisture in the soil, help reduce erosion of soil surface, and when degraded, will yield nutrient to palm trees. This is in accordance with Teerapong Jungniyom (2008) who wrote that empty palm bunch was used as a material for mushroom cultivation. But there would be more utilization and more value added than mushroom cultivation thanks to the tough fiber in the core of the empty palm bunch that could be used to replace fiber from coconut shell, and with high nutrients, could be used as material for good quality composting.

3) Residues from palm oil extracting plants such as palm kernel meal, waste palm fiber, sludge can produce compost and animal feed, and palm kernel shell can produce biomass energy. This is in accordance with Seksan Papong et al (2014) who stated that biomass waste such as empty palm bunch, fiber from palm shell, palm kernel shell, palm kernel meal, and sludge from palm oil had the potential for production of organic fertilizers, power generation and heat energy generation, or production of wood replacing materials. Moreover, it can be used as ingredient in the production of animal feed to reduce environmental burden from the production of raw material. The utilization of oil palm's residues will reduce waste derived from oil palm and palm oil production processes as Zero Waste process in the oil palm industry. It means the total utilization of waste or production process without waste. This is in accordance with Teerapong Jungniyom (2008) who stated that it was found that in the palm oil extracting industry, there was over $70 \%$ of waste from oil palm extraction. The waste would cause environment problems. Therefore, the utilization of the waste not only protects the environment but also generates more income to palm oil extracting plants. The income will be used to purchase raw material (palm bunch), resulting in more stable palm bunch prices. It will also generate income from the sales of products, reduce costs in purchasing chemical fertilizers, reduce use of chemical fertilizers, resulting in less impact on the environment. This is in line with Seksan Papong et al (2014) who wrote that the production of oil palm affected 
the environment from the production process and the use of chemical fertilizers. The impact on the environment from the oil palm cultivation process would affect the environment in the entire production chain. Therefore, the reduced use of chemical fertilizers will reduce the impact on the environment caused by oil palm and continuous products.

\section{Recommendations}

\section{Recommendations for the Utilization of Research Works}

1) Relevant agencies such as Department of Agriculture Extension, Department of Agriculture, Provincial Agriculture Offices, District Agriculture Offices can use the research works as a guideline to support agricultural activities of oil palm growers, advise on practice, promote knowledge, media, or technology to appropriately assist the growers.

2) Farmers and communities can apply research works to increase economic value added, reduce uncertain income or insufficient investment return, resulting in farmers' sustainable occupation.

3) Production of organic fertilizers from oil palm's residues can be used in agriculture to reduce costs in purchasing chemical fertilizers and reduce pollution problems.

4) Palm oil extracting plants can use the residues as biomass fuel in their production process to reduce costs in purchasing fuel.

\section{References}

Chanjula, P. (2015). Development and Utilization of Oil Palm Production and By-Product as Animal Feed: II. Utilization of Palm Kernel Cake for Ruminants. Songklanakarin Journal of Plant Science, 2 (2), 1-12.

Department of Agriculture Extension.(n.d.). Knowledge management of palm bunch used in oil palm plantation. Retrieved March 16, 2017, from km.doae.go.th/bestpractice/uploadfile/bestkrabi0001.doc

Department of Agriculture. (2008). Management of palm oil. Retrieved March 7, 2017, from $\mathrm{http} / /:$ www.doa.go.th/palm/linkTechnical/management.html

Department of Agriculture. (2008). Palm oil processing. Retrieved March 7, 2017, from $\mathrm{http} / /$ :www.doa.go.th/palm/linkTechnical/oil\%20palm\%20processing.html

Eksomtramage, T. (2009). Development of production technology, value of palm oil and supplementary income of palm oil farmers. The Thailand Research Fund.

Jungniyom, T. (2008). Zero - waste Process in Oil Palm Extraction Industries. Hatyai Journal, (2)6, .164-159

Jungniyom, T., \& Pengnoo, A. (2008). Production of compost from palm oil mill wastes. Prince of Songkla University.

Papong, S. (2014). A Study for Guidelines on Sustainable Management of the Palm Oil and its Related Products. Agricultural Research Development Agency (Public Organization).

Phoochinda, W. (2015). Guidelines to promote agricultural oil palm to reduce greenhouse gases according to the standard of Thailand. Agricultural Research Development Agency (Public Organization).

\section{Copyrights}

Copyright for this article is retained by the author(s), with first publication rights granted to the journal.

This is an open-access article distributed under the terms and conditions of the Creative Commons Attribution license (http://creativecommons.org/licenses/by/4.0/). 